\title{
Self-Efficacy of Internship Nursing Students in Dealing with Palliative Patients
}

\author{
Rani.A.Sipayung, Tuti Pahria, Atlastieka Praptiwi \\ Faculty of Nursing Universitas Padjadjaran \\ E-mail : ranisipayung95@gmail.com
}

\begin{abstract}
Palliative care is one of the practice areas that is perceived difficult by nurses and nursing students. Students tend to avoid seeing patients with the deteriorating condition. This research aimed to identify the self-efficacy of internship nursing students in facing palliative patients within communication, management of the patient, and multidisciplinary teamwork components. This study was a descriptive quantitative. Samples were recruited from a population of internship nursing students at Faculty of Nursing Universitas Padjadjaran using a total sampling technique $(\mathrm{n}=159)$. Data were collected using Self-Efficacy Palliative Care scale (SEPC). Data were analyzed using mean scores calculated from the total scores of each respondent. The results showed that more than half of the respondents had a low level of self-efficacy. In terms of its components, students' self-efficacy in communication, multidisciplinary team collaboration, and patient management had a mean score of 38.24 (SD 10.35), 39.21 (SD 9.44), and 48.18 (SD 9.56) respectively. Based on the results, it is recommended to develop an active learning strategy for internship nursing students, especially in the aspects of communication, patient management, and multidisciplinary team collaboration.
\end{abstract}

Keywords: Internship nursing students, palliative care, self-efficacy. 
Rani A. Sipayung: Self-Efficacy of Internship Nursing Students in Dealing with Palliative Patients

\section{Introduction}

Palliative care is an approach of the health professionals team that is carried out to improve the quality of life of patients and families in dealing with life-threatening disease problems, through prevention and stopping the suffering of patients after being diagnosed with incurable diseases, and reducing other problems such as physical, psychosocial disorders, and spiritual (World Health Organization [WHO], 2005). According to the National Consensus Project (NCP) (2004), the aim of palliative care is to prevent and alleviate suffering in patients, provide support to improve the quality of life that is good for patients and their families, assist decision making, and provide opportunities to self-development.

The need for giving palliative care has increased every year, this may because of the increasing number of elderly and chronic diseases patients (World Health Assembly [WHA], 2014). Chronic disease cases are common in the adult population, such as cardiovascular disorders $(38.5 \%)$, cancer (34\%), Chronic Obstructive Respiratory Disease (COPD) (10.3\%), Acquired Immune Deficiency Syndrome (AIDS) (5,7 \%), and diabetes $(4.6 \%)$, several diseases also require palliative care including kidney failure, chronic liver disease, Parkinson's, rheumatoid arthritis, neurological disorders, dementia, congenital anomalies, and retention of Tuberculosis drugs (WHO, 2014 )

Research on palliative care was carried out by Agustina, Anna, Praptiwi, and Solehati (2014) at one of the national referral hospitals, the study found that nurses had difficulty in communicating with multidisciplinary teams and had difficulties in reducing patients' symptoms when providing nursing care to palliative patients. Qualitative research (n $=8$ ) on nurses in the Neurosurgical Critical Care Unit showed that NCCU nurses had difficulty in determining the phase of death in patients because nurses only monitor the patient's condition through monitor screens and patients' vital signs (Enggune, Ibrahim, and Agustina, 2014). The difficulty faced by nurses in providing nursing care to palliative patients because each room has a different level of difficulty.
Research on palliative care conducted in Australia on nurses $(\mathrm{n}=25)$ shows that nurses have a passive role in providing care to patients with end life conditions, it because of nurses feel uncomfortable and less prepared (Bloomer, Endacott, O'Connor, \& Cross, 2015 ) They also feels that they have a lack of role in providing care before death, nurses only do routine care (Bloomer et al., 2015). Giving counseling about death, offering food as patients' culture, and counseling on funeral planning are not well consulted by nurses (Kisvetrova, Skoloudik, Joanovic, Konecna, \& Miksova, 2016). While, patients' need to obtain services, and respect dignity. Fulfilling the patient's expectation in accordance with the patient's culture would increase the patient's dignity, and their self-esteem before death (Hemati, et al., 2016).

Several studies were conducted on 10 nursing students in providing care to palliative patients in Australia, the study found that nursing students had a feeling of helplessness and inability to make decisions. The inability is because they still consider themselves as students (Henderson, Rowe, Watson, \& Holmes, 2016). Communication is one of the important things in providing care for palliative care, but in nursing practice, there are difficulties in communicating with patients. Research conducted by Ferguson and Cosby (2017) with quantitative mixed simulation methods and simulation experience in nursing students showed that there are 4 difficulties in providing palliative care. The difficulties include the existence of things that are unknown, meet the needs and dignity of patients, prepare patients to face end-life, and communication. Based on these 4 difficulties, the majority of students state that they have difficulty in communicating with patients, nursing students prefer to be quiet if they don't know what to say (Ferguson \& Cosby, 2017).

Based on these difficulties, education about palliative care would affect the level of self-efficacy of nursing students, a high level of self-efficacy would increase the ability of individuals to do something difficult (Bandura, 1994). If a person has low self-efficacy, he would avoid something he considers difficult (Bandura, 1994). The level of self-efficacy of nursing students has a significant relationship 
Rani A. Sipayung: Self-Efficacy of Internship Nursing Students in Dealing with Palliative Patients

with stress levels and how students overcome difficult situations. If a student's self-efficacy is low, they would have a high level of stress (Bodys-Cupak, Majda, Zalewska-Puchala, \& Kaminska, 2016). Providing material regarding palliative care is needed to improve the knowledge and skills of nurses related to palliative care.

Behavior in dealing with palliative patients is influenced by 4 factors, including, knowledge and skills, self-efficacy, perceived expected results, and personal and practical support (Parle, Maguire, \& Heaven, 1997). Self-efficacy is a determinant of the perception of nursing students who have just graduated from readiness to enter clinical practice, especially palliative care (Henderson, Rowe, Watson, \& Holmes, 2016). Self-efficacy in the education system would evaluate the success of education that has been given, especially in the nursing profession (George, Locasto, \& Pyo, 2017). In addition, according to George et al. (2017), the level of self-efficacy can be used to measure the ability of nursing students during their education to become health workers, namely professional nurses. Research on the level of self-efficacy of nursing students in dealing with palliative patients has been carried out overseas with qualitative research methods, and publications have not been found in Indonesia. So this research is important because there are cultural differences between Indonesia and other countries. This research was also conducted to assess an overview of the level of self-efficacy of internship nursing students (PPN) in dealing with palliative patients.

\section{Research Method}

The research design was descriptive quantitative. This study sample was PPN student of Nursing Faculty, Universitas Padjajaran. They were chosen using the total sampling technique from the VAT student population in batches 34 and $35(\mathrm{n}=159)$. Data was collected using a questionnaire to identify respondents' characteristics and the instrument used to measure student self-efficacy. The Palliative Care scale was another instrument (SEPC) to assess several components including the communication component, patient management, and multidisciplinary teamwork on palliative patients consisting of 23 items of statements (Mason \& Ellershaw, 2004). Each item measured using the Visual Analogue Scale (VAS) $0-10 \mathrm{~cm}$, where this instrument uses the answer choice range from "very nervous" to "very confident." The SEPC instrument has been translated from English to Indonesian, and a back translation method has been carried out to see the consistency of the substance. Student's efficacy is categorized as high if the total score is from resp on $<$ mean score, which is 125.64 and is categorized as a low total score of respondents score the average score. Data are presented in the form of frequency distribution tables to explain the characteristics of VAT students and their level of self-efficacy.

This study applied informed consent so that respondents who have returned questionnaires to researchers are considered to have given consent in this study. Data collection is done by distributing questionnaires directly to VAT students and for VAT students who are serving in the hospital, questionnaires are submitted to each group representative who has been contacted. The researcher personally contacted each respondent, to provide an explanation and ask for the questionnaire that had been given to the group representatives themselves. After all the questionnaires were collected, the researcher took the questionnaire to the group representatives. This research has obtained research permission from the Ethics Committee of Universitas Padjadjaran Number: 607 / UN6.KEP / EC / 2018 and has obtained research permission from the Nursing Faculty of Padjadjaran University in number 2397 / UN6.L / LT / 2018.

\section{Research Results}

The characteristics of PPN students in this study consisted of gender, age, group of study, and experience in dealing with palliative patients. Table 1 shows that the majority of VAT students were women. Age categories were in late adolescence (17-25 years). VAT students of class 34 who participated 
Rani A. Sipayung: Self-Efficacy of Internship Nursing Students in Dealing with Palliative Patients

in this study were $98.98 \%$, while those in VAT students in class 35 were $92.42 \%$. On the characteristics of experience in dealing with palliative patients, nearly $70 \%$ of VAT students who already have experience and the majority are VAT 34 student.

Table 1 Characteristic of PPN students ( $n=159)$

\begin{tabular}{lcc}
\hline \multicolumn{1}{c}{ Characteristic } & Frequency (f) & Percentase (\%) \\
\hline Sex & 20 & \\
Male & 139 & 12.58 \\
Female & & 87.42 \\
Age & 124 & \\
Early Adolescent (17-25 years) & 15 & 77.99 \\
Early Adult (35 years) & 20 & 9.43 \\
Late Adults (36-45 years) & & 12.58 \\
Group of PPN & 98 & \\
34 & 61 & 61.64 \\
35 & & 38.36 \\
\hline Experience in Dealing with & 106 & \\
Palliative Patients & 53 & 66.67 \\
Yes & & 33.33 \\
No & & \\
\hline
\end{tabular}

Table 2 Self-Efficacy levels of PPN students $(\mathrm{N}=159)$

\begin{tabular}{ccc}
\hline Category & f & \% \\
\hline High level of Self-Efficacy & 77 & 48.43 \\
Low level of Self-Efficacy & 82 & 51.57 \\
\hline
\end{tabular}

Table 3 Mean value of Self-Efficacy level of PPN students ( $n=159)$

\begin{tabular}{lccccc}
\hline \multicolumn{1}{c}{ Variable } & $\begin{array}{c}\text { Range of SEPC } \\
\text { Score }\end{array}$ & Mean & SD & Min. & Max \\
\hline Self-efficacy & $0-230$ & 125.64 & 25.42 & 57.8 & 196.9 \\
Communication & $0-80$ & 38.24 & 10.35 & 7.6 & 68.9 \\
Patients & $0-80$ & 48.18 & 9.56 & 23.1 & 73.7 \\
Management & $0-70$ & 39.21 & 9.44 & 9.6 & 65.7 \\
$\begin{array}{l}\text { Multi-discipline } \\
\text { Collaboration }\end{array}$ & & & & & \\
\hline
\end{tabular}

Table 4 Cross-tabulation of Self-Efficacy levels of PPN student ( $N=159)$

\begin{tabular}{llccc}
\hline \multirow{2}{*}{ Characteristic Students } & \multicolumn{4}{c}{ Self-efficacy levels } \\
\cline { 2 - 5 } & \multicolumn{1}{c}{ High } & Low & \% \\
\cline { 2 - 5 } & $\mathbf{f}$ & & $\mathbf{f}$ & \\
\hline Sex & & 55 & 9 & 45 \\
Male & 11 & 47.48 & 73 & 52.52 \\
Female & 66 & & & \\
Age & & 44.35 & 69 & 55.65 \\
Early Adolescent (17-25 years) & 55 & 73.33 & 4 & 26.67 \\
Early Adult (35 years) & 11 & & & \\
\hline
\end{tabular}


Rani A. Sipayung: Self-Efficacy of Internship Nursing Students in Dealing with Palliative Patients

\begin{tabular}{lcccc}
\hline Late Adults (36-45 years) & 11 & 55 & 9 & 45 \\
Group of PPN & 54 & 55.10 & 44 & 44.90 \\
34 & 23 & 37.70 & 38 & 62.30 \\
35 & & & & \\
Experience in Dealing with & 59 & 55.66 & 47 & 44.34 \\
Palliative Patients & 18 & 34 & 35 & 66 \\
Yes & & & \\
No & & & \\
\hline
\end{tabular}

The following table presents the results of data analysis between the total scores of VAT students with mean values. Based on Table 2 , the proportion of VAT students who have high and low self-efficacy levels is almost the same

Table 3 describes the result of calculating the mean self-efficacy based on the total score of the three components and the mean value based on the total score on each component. Based on the mean value in Table. 3 below, the lowest mean value in the communication component was $38.24(\mathrm{SD}=10.35)$.

Table 4 presents a cross tabulation between the level of self-efficacy and characteristic of respondents. Table 4 shows that more than half of male respondents have a high level of self-efficacy. Whereas, more than half of female respondents have low levels of selfefficacy. The high level of self-efficacy was shown in respondents with the initial adult age category with a percentage of $73.3 \%$, besides that more than half of the VAT students in class 34 also had a high level of self-efficacy. Whereas in the VAT student class of 35 the majority had a low level of self-efficacy with a percentage of $62.30 \%$. High levels of self-efficacy are also shown in VAT students who already have experience dealing with palliative patients, where more than half have high levels of self-efficacy

\section{Discussion}

Based on the results of the study in Table. 2 the level of high and low self-efficacy in VAT students has almost the same proportion. More than half of VAT students have low levels of self-efficacy. The low level of self-efficacy in the VAT students would cause students to show avoidance behavior when facing palliative patients (Bandura,
1994). If the level of self-efficacy in PPN students is high, then VAT students consider difficulties as a challenging part of the study (Bandura, 1994). In addition, according to Parle, Maguire, and Heaven (1997), low selfefficacy will lead to perceptions of poorly expectation, so that it would cause negative behavior. Low self-efficacy in individuals would cause poor support that comes from self and the practical environment so that it can lead to negative behavior in individuals (Parle, Maguire, \& Heaven, 1997). Research conducted by Henderson et al. (2016) where nursing students have difficulties and feel less confident in providing palliative care. The student would avoid standing in a corner of the room and calling for help if the patient's condition deteriorates (Henderson et al., 2016). Research conducted by Henderson et al. (2016) shows that the low level of selfefficacy in students is because of students consider themselves to have small roles in providing palliative care.

The results of short interviews conducted with VAT students $(n=2)$ of batch 34 , students experienced difficulties when facing palliative patients. This difficulty is shown in the communication component which has the lowest mean value. According to Ferguson and Cosby (2017), communication is one of the most difficult things for students in dealing with palliative patients, and students prefer to do non-verbal communication. Item statement "Discussing the patient's death (with the patient)" found in the communication component has the lowest mean value. Based on the open questions contained in the questionnaire regarding experience during dealing with palliative patients, respondents said that they had difficulty controlling emotions while providing palliative care.

Based on the number of VAT students age group (17-25 years) $44.35 \%$ have a low level 
Rani A. Sipayung: Self-Efficacy of Internship Nursing Students in Dealing with Palliative Patients

of self-efficacy. This may happen because the late adolescence age is a transition period to enter adulthood which must be fully responsible for itself (Bandura, 1994). Change of roles makes individuals isolate themselves and not ready to face difficulties that might occur (Bandura, 1994). However, the transition from adolescence to adulthood depends on the level of self-efficacy with mastery of previous experience (Bandura, 1994). The majority of early adulthood and young adults have a high level of self-efficacy. However, the level of self-efficacy would change if the individual afraid to compete with a younger competitor (Bandura, 1994).

In the VAT student class 34, more than half of the respondents had a high level of self-efficacy with a percentage of $55.10 \%$. Whereas in the VAT student class of 35 the majority had a low level of self-efficacy with a percentage of $62.30 \%$. This may occur because 34th grade VAT students have passed the palliative care subject, as $(\mathrm{n}=21)$ VAT students in batch 34 took elective palliative care courses. According to Parle, Maguire, and Heaven (1997) said that good knowledge and skills will increase individual self-efficacy. This shows that increasing knowledge about palliative care would provide views on palliative care, train students to interact with patients, and prepare themselves to be able to provide maximum palliative care (Ballesteros, Centeno, and Arantzamendi, 2014).

The results of this study indicate that the mean value of the total score and the mean value from each component were below the expectation. Thus, there is still a need to develop palliative care for VAT students to increase the mean score for all components.

\section{Conclusion}

The proportion of PPN students have the same level of self-efficacy. According to the 3 components, the component of communication and collaboration of multidisciplinary teams has a low mean value. Whereas in the management component of the patient has a high mean value. However, the mean value shows low results from perfect values.
Basedontheresultsofthisstudy, suggestions that can be made for further research is the study of the effect of learning methods on the level of self-efficacy to determine the effect of education on the level of self-efficacy in VAT and academic students. Suggestions for the use of the Self-Efficacy Palliative Care questionnaire (SEPC) in subsequent studies, to consider standardization in the use of scoring mean scores from the results of filling in respondents. In the VAT student class 34, more than half of the respondents had a high level of self-efficacy with a percentage of $55.10 \%$. Whereas in the VAT student class of 35 the majority had a low level of self-efficacy with a percentage of $62.30 \%$. This can occur because 34th grade VAT students have passed the palliative care stage and as many as (n $=21$ ) VAT students in batch 34 take elective palliative care courses. According to Parle, Maguire, and Heaven (1997) said that good knowledge and skills will increase individual self-efficacy. This shows that increasing knowledge about palliative care can provide views on palliative care, can train students to interact with patients, and students can prepare themselves to be able to provide maximum palliative care (Ballesteros, Centeno, and Arantzamendi, 2014).

The results of this study indicate that the mean value of the total score and the mean value based on each component has a result that is far from the perfect value. Thus, there is still a need to develop palliative care for VAT students to increase the mean score for all components.

Educational institutions are expected to apply active learning in palliative care such as discussing a video that shows a discussion process among a nurse, patients, and family. Conducting practice in listening to patient symptoms by role modeling as patients and nurses, and case simulations to learn how to do assessment properly, determine diagnoses, and nursing interventions.

Based on the results of this study, the future study is to examine the effect of learning methods on the level of selfefficacy which aims to determine the effect of education on the level of self-efficacy on VAT and academic students. For users of the SelfEfficacy Palliative Care (SEPC) questionnaire to consider the standardization of the mean 
Rani A. Sipayung: Self-Efficacy of Internship Nursing Students in Dealing with Palliative Patients

score from the results data collection.

\section{References}

Agustina, H. R., Anna, A., Praptiwi, A., \& Solehati, T. (2014). Kajian Pengetahuan, Sikap, Praktik dan Kesulitan Perawat dalam Melaksanakan Perawatan Paliatif di Rumah Sakti Pemerintah di Propinsi Jawa Barat. Laporan Akhir. Penelitian Hibah Fakultas. Retrieved from pustaka.unpad. ac.id/wp-content/uploads/2016/11/06-kajianpengetahuan.pdf.

Ballesteros, M., Centeno, C., \& Arantzamendi, M. (2014). A qualitative exploratory study of nursing students' assessment of the contribution of palliative care learning. Nurse Education Today, 34(6). https://doi. org/10.1016/j.nedt.2013.12.010.

Bandura, A. (1994). Bandura Self-efficacy defined. Encyclopedia of Human Behavior. Retrieved from http://www.uky.edu/ eushe2/ Bandura/BanEncy.html.

Bloomer, M. J., Endacott, R., O'Connor, M., \& Cross, W. (2015). The 'dis-ease' of dying: Challenges in Nursing Care of The Dying in The Acute Hospital Setting. Palliative Medicine, 757-764: doi: 10.1177/0269216313477176.

Bodys-Cupak, I., Majda, A., ZalewskaPuchala, J., \& Kaminska, A. (2016). The impact of a sense of self-efficacy on the level of stress and tha ways of coping with difficult situations in Polish nursing students. Nurse Education Today 45, 102-107: doi : http:// dx.doi.org/10.1016/j.nedt.2016.07.004.

Effendy, C. (2014). Pengembangan Manajemen Pelayanan Paliatif. Jurnal Manajemen Pelayanan Kesehatan, 17(1), 182-187. https://doi.org/10.9774/ jmk.13.1.61-75.

Enggune, M., Ibrahim, K., Agustina, H. R. (2014). Persepsi perawat neurosurgical critical care unit terhadap perawatan pasien menjelang ajal. Jurnal Keperawatan Padjadjaran, 2.
Ferguson, R., \& Cosby, P. (2017). Nursing Students' Attitudes and Experiences Toward End-of-Life Care: A Mixed Methods Study Using Simulation. Clinical Simulation in Nursing, 13(8), 343-346. https://doi. org/10.1016/j.ecns.2017.03.006.

George, L. E., Locasto, L. W., Pyo, K. A., \& W. Cline, T. (2017). Effect of the dedicated education unit on nursing student selfefficacy: A quasi-experimental research study. Nurse Education in Practice, 23, 48-53. https://doi.org/10.1016/j.nepr.2017.02.007.

Hemati, Z., Ashouri, E., AllahBakhshian, M., Pourfarzad, Z., Shirani, F., Safazadeh, S., et al. (2016). Dying with dignity: a concept analysis. Journal of Clinical Nursing, 25, 1218-1228: doi: 10.1111/jocn.13143.

Henderson, A., Rowe, J., Watson, K., \& Holmes, D. H. (2016). Graduating nurse selfefficacy in palliative care practice. Nurse Educational Today, 139-146: doi: http:// dx.doi.org/10.1016/j.nedt.2016.01.005.

Kementrian Kesehatan Republik Indonesia (Kemenkes RI). 2017. Layanan Paliatif Bebaskan Nyeri Kanker. http://www.depkes. go.id/article/print/17110300002/layananpaliatif-bebaskan-nyeri-kanker.html, (diakses pada 10 Maret 2018).

Kisvetrova, H., Skoloudik, D., Joanovic, E., Konecna, J., \& Miksova, Z. (2016, November Cheko). Dying Care Intervention in the Intensive Care Unit. Journal of Nursing Scholarship, 139-146: doi: 10.1111/ jnu. 12191

Mason, S. \& Ellershaw, J. (2004). Assessing undergraduate palliative care education: validity and reliability of two scales examining perceived efficacy and outcome expectancies in palliative care. Med Educ ,38(10); 1103-10.

NCP. (2004). National consensus project for quality palliative care: Clinical practice guidelines for quality palliative care, executive summary. (M. A. Liebert, Ed.) Journal of Palliative Medicine, 7. 
Rani A. Sipayung: Self-Efficacy of Internship Nursing Students in Dealing with Palliative Patients

Parle, M., Maguire, P., \& Heaven, C. (1997). The development of a training model to improve health professionals' skills, selfefficacy and outcome expectancies when communicating with cancer patients. Elsevier 44, 231-240: doi: https://doi.org/10.1016/ S0277-9536(96)00148-7.

Satria. (2014). Perawatan Paliatif di Indonesia Belum Optimal. https://ugm.ac.id: https://ugm.ac.id/id/berita/8759-perawatan. paliatif.di.indonesia.belum.optimal, (diakses pada 13 Januari 2018).

WHA (World Health Assembly). (2014). Strengtheningofpalliativecareas acomponent of comprehensiv care throughout the life course. http://apps.who.int/medicinedocs/ documents/s21454en/s21454en.pdf, (diakses pada 18 Februari 2018).

WHO (World Health Organization). (2005). Definition of Palliative Care. http://www. who.int/cancer/palliative/definition/en/, (diakses pada 6 Januari 2018).

(2014). Global atlas of palliative care at the end of life. (S. R. Connor, \& M. C. Bermedo, Eds.) All Rights Reserved.

Witjaksono, M.A., Sutandiyo, N., \& Suardi, D. (2014). Regional support for palliative care in Indonesia. http://www.ehospice.com/ ArticleView/tabid/10686/ArticleId/11661/ language/en-GB/Default.aspx, (diakses pada 17 Februari 2018). 